\title{
Physicochemical and Spectroscopic Properties of Biofield Energy Treated Protose
}

\author{
Mahendra Kumar Trivedi ${ }^{1}$, Alice Branton ${ }^{1}$, Dahryn Trivedi ${ }^{1}$, Gopal Nayak ${ }^{1}$, Khemraj Bairwa ${ }^{2}$, \\ Snehasis Jana ${ }^{2, *}$ \\ ${ }^{1}$ Trivedi Global Inc., Henderson, NV, USA \\ ${ }^{2}$ Trivedi Science Research Laboratory Pvt. Ltd., Bhopal, Madhya Pradesh, India
}

Email address:

publication@trivedisrl.com (S. Jana)

\section{To cite this article:}

Mahendra Kumar Trivedi, Alice Branton, Dahryn Trivedi, Gopal Nayak, Khemraj Bairwa, Snehasis Jana. Physicochemical and Spectroscopic Properties of Biofield Energy Treated Protose. American Journal of Biomedical and Life Sciences. Vol. 3, No. 6, 2015, pp. 104-110. doi: 10.11648/j.ajbls.20150306.11

\begin{abstract}
Protose is the enzyme digest of mixed proteins that is recommended for culture media, bulk production of enzymes, antibiotics, toxins, veterinary preparations, etc. This study was proposed to evaluate the effect of biofield energy treatment on the physicochemical and spectroscopic properties of protose. The study was achieved in two groups i.e. control and treated. The control group was remained as untreated, while the treated group was received Mr. Trivedi's biofield energy treatment. Finally, both the control and treated samples were evaluated using various analytical techniques. The X-ray diffractograms (XRD) of control and treated samples showed the halo patterns peak that suggested the amorphous nature of both the samples of protose. The particle size analysis showed about $12.68 \%$ and 90.94 increase in the average particle size $\left(\mathrm{d}_{50}\right)$ and $\mathrm{d}_{99}$ (particle size below which $99 \%$ particles are present) of treated protose with respect to the control. The surface area analysis revealed the $4.96 \%$ decrease in the surface area of treated sample as compared to the control sample. The differential scanning calorimetry (DSC) analysis revealed the $22.49 \%$ increase in the latent heat of fusion of treated sample as compared to the control. Thermogravimetric analysis (TGA) analysis showed increase in maximum thermal degradation temperature $\left(\mathrm{T}_{\max }\right)$ by $5.02 \%$ in treated sample as compared to the control. The increase in $T_{\max }$ might be correlated with increased thermal stability of treated sample as compared to the control. Fourier transform infrared (FT-IR) study showed the alteration in the vibrational frequency of functional groups like $\mathrm{N}-\mathrm{H}, \mathrm{C}-\mathrm{H}$, and $\mathrm{S}=\mathrm{O}$ of treated protose as compared to the control sample. Based on the overall analytical results, it is concluded that Mr. Trivedi's biofield energy treatment has a significant impact on the physicochemical and spectral properties of protose. As a result, the treated protose might be more effective as a culture medium than the corresponding control.
\end{abstract}

Keywords: Biofield Energy Treatment, Protose, X-ray Diffraction, Particle Size Analysis, Surface Area Analysis, Differential Scanning Calorimetry, Fourier Transform Infrared Spectroscopy

\section{Introduction}

Growth medium or culture medium is a liquid or gel that is designed for the growth of microorganisms, cells or small plants such as moss [1]. Different types of media are available for the growth of different types of cells such as nutrient broths and agar plates [2]. Protose is a specially developed product containing various combinations of proteoses, peptones and amino acids [3]. It is an enzymatic digest of mixed proteins, and recommended for fermentation and vaccine industries $[4,5]$. It is an exceptionally light colored peptone, which gives clear solution. It is used in culture media for bulk production of enzymes, antibiotics, toxins, veterinary preparations, etc. [6].

Despite lots of applications of culture media, the thermal stability and chemical stability are the important attributes of any culture media. Therefore, an alternate methodology is required, which can improve the thermal as well as chemical stability of culture media such as protose. Recently, biofield energy treatment has been assessed in the numerous fields and reported to alter numerous properties of living organisms and non-living things $[7,8]$.

Biofield energy treatment is a type of energy therapy (putative energy fields) that has been considered as energy therapy by the National Institute of Health/National Center for Complementary and Alternative Medicine (NIH/NCCAM) [9] 
The energy therapies include magnet therapy, bio-electromagnetic therapy, healing touch, etc. and comprise low-level of energy field exchanges [10]. The human body has the unique bioenergetics field that consists of energy structures such as biophotons [11]. The biophoton is non-thermal origin in the UV-visible spectrum, emitted from a biological system. These biophotons contain informations that regulate all the system of human body in order to communicate and work coherently [12]. This is generally observed in the healthy condition of human body. However, these biophotons are disordered in diseased conditions; resulting in communication problems among cells, organs, and energy systems [13]. For instance, the cancer cells are discordant with the rest of cells of body, which result in uncontrolled growth and lead to endanger the survival of the body [14].

The practitioners or specialists of energy medicine modulate and balance this bioenergetic field via harnessing the energy from the Universe [15]. Hence, the biofield energy treatment is the practice wherein the human harness the energy from environment and transmit it to any living or nonliving object on the Globe. Mr. Mahendra Kumar Trivedi possesses a unique biofield energy; and his biofield energy treatment is known as The Trivedi Effect ${ }^{\circledR}$. Recently, Mr. Trivedi's biofield energy treatment is reported to improve the growth of plants and quality and quantity of plant products like blueberry, ginseng, tomato, etc. [16, 17]. Moreover, the contents of chlorophyll ( $a$ and $b$ ) were also found increased after the biofield energy treatment with respect to the control [18]. The biofield treatment has also modified the spectral and physicochemical properties of organic products such as beef extract and meat infusion powder [19].

Hence, considering the impact of biofield energy treatment, this study was aimed to evaluate the effect of biofield treatment on the protose using various analytical techniques.

\section{Materials and Methods}

\subsection{Study Design}

Protose was procured from HiMedia Laboratories, India, and divided into two groups i.e. control and treated. The control sample was kept without treatment while the treated sample was handed over in sealed pack to Mr. Trivedi for the biofield energy treatment. Mr. Trivedi rendered the biofield energy treatment to the treated group via his unique energy transmission process under standard laboratory conditions. Afterward, the treated and control samples were evaluated using several analytical techniques such as X-ray diffractometry (XRD), particle size analysis, surface area analysis, differential scanning calorimetry (DSC), thermogravimetric analysis-derivative thermogravimetry (TGA/DTG), and Fourier transform infrared (FT-IR) spectroscopy.

\subsection{XRD Study}

The XRD study of protose samples (control and treated) was done on Phillips (Holland PW 1710) X-ray diffractometer. The system was equipped with nickel filter and copper anode, the wavelength was set to $1.54056 \AA$.

\subsection{Particle Size Analysis}

The particle size of control and treated protose was determined using laser particle size analyzer (Sympatec HELOS-BF) at the detection range of $0.1-875 \mu \mathrm{m}$. The particle size data were obtained in the form of a chart of particle size $v s$. cumulative percentage. The average particle sizes $\mathrm{d}_{50}$ was deduced using particle size distribution curve. The percent change in average particle size was calculated using following equation.

$$
\begin{aligned}
& \% \text { change in particle size, } d_{50} \\
& =\frac{\left[\left(d_{50}\right)_{\text {Treated }}-\left(d_{50}\right)_{\text {Control }}\right]}{\left(d_{50}\right)_{\text {Control }}} \times 100
\end{aligned}
$$

Where, $\left(\mathrm{d}_{50}\right)$ Control and $\left(\mathrm{d}_{50}\right)$ Treated are the average particle size of control and treated samples, respectively; similarly the $\mathrm{d}_{99}$ was calculated.

\subsection{Surface Area Analysis}

The surface area of control and treated protose was analyzed based on the ASTM D 5604 method using the Brunauer-Emmett-Teller (BET) surface area analyzer (Smart SORB 90). The instrument range was set to $0.2 \mathrm{~m}^{2} / \mathrm{g}$ to 1000 $\mathrm{m}^{2} / \mathrm{g}$. The following formula was used for the percent change in surface area

$$
\% \text { change in surface area }=\frac{\left[\mathrm{S}_{\text {Treated }}-\mathrm{S}_{\text {Control }}\right]}{\mathrm{S}_{\text {Control }}} \times 100
$$

Here, $\mathrm{S}_{\text {Control }}$ and $\mathrm{S}_{\text {Treated }}$ is the surface area of control and treated samples, respectively.

\subsection{DSC Study}

The melting temperature and latent heat of fusion of control and treated protose were determine using the Pyris- 6 Perkin Elmer differential scanning calorimeter. The analytes were heated at the rate of $10^{\circ} \mathrm{C} / \mathrm{min}$ under the air atmosphere with flow rate of $5 \mathrm{~mL} / \mathrm{min}$. An empty pan sealed with cover lid was used as the reference pan. The latent heat of fusion $(\Delta \mathrm{H})$ and the melting temperature $\left(\mathrm{T}_{\mathrm{m}}\right)$ of both the control and treated samples were obtained from the DSC thermograms.

\subsection{TGA/DTG Analysis}

The TGA/DTG analysis of both control and treated samples of protose was carried out on Mettler Toledo simultaneous TGA/DTG analyzer. The analytes were heated up to $400^{\circ} \mathrm{C}$ from the room temperature, at the heating rate of $5^{\circ} \mathrm{C} / \mathrm{min}$, under the air atmosphere. The onset temperature of thermal degradation and temperature at which maximum weight loss occur $\left(\mathrm{T}_{\max }\right)$ in samples were obtained from the TGA/DTG thermogram. 


\subsection{FT-IR Spectroscopic Characterization}

The FT-IR spectroscopy of both the control and treated samples of protose was carried out to ascertain the effect of biofield energy treatment on molecular level like dipole moment, force constant, and bond strength in chemical structure [20]. The samples were prepared by crushing the powdered protose sample with spectroscopic grade $\mathrm{KBr}$ into fine powder and then pressed into pellets. The FT-IR spectra were acquired from the Shimadzu's Fourier transform infrared spectrometer (Japan) in the frequency region of $500-4000 \mathrm{~cm}^{-1}$.

\section{Results and Discussion}

\subsection{XRD Analysis}

The XRD diffractograms of protose samples (control and treated) are shown in Fig. 1. Both the control and treated samples showed the broad halo at $2 \theta$ equal to $20.6^{\circ}$.
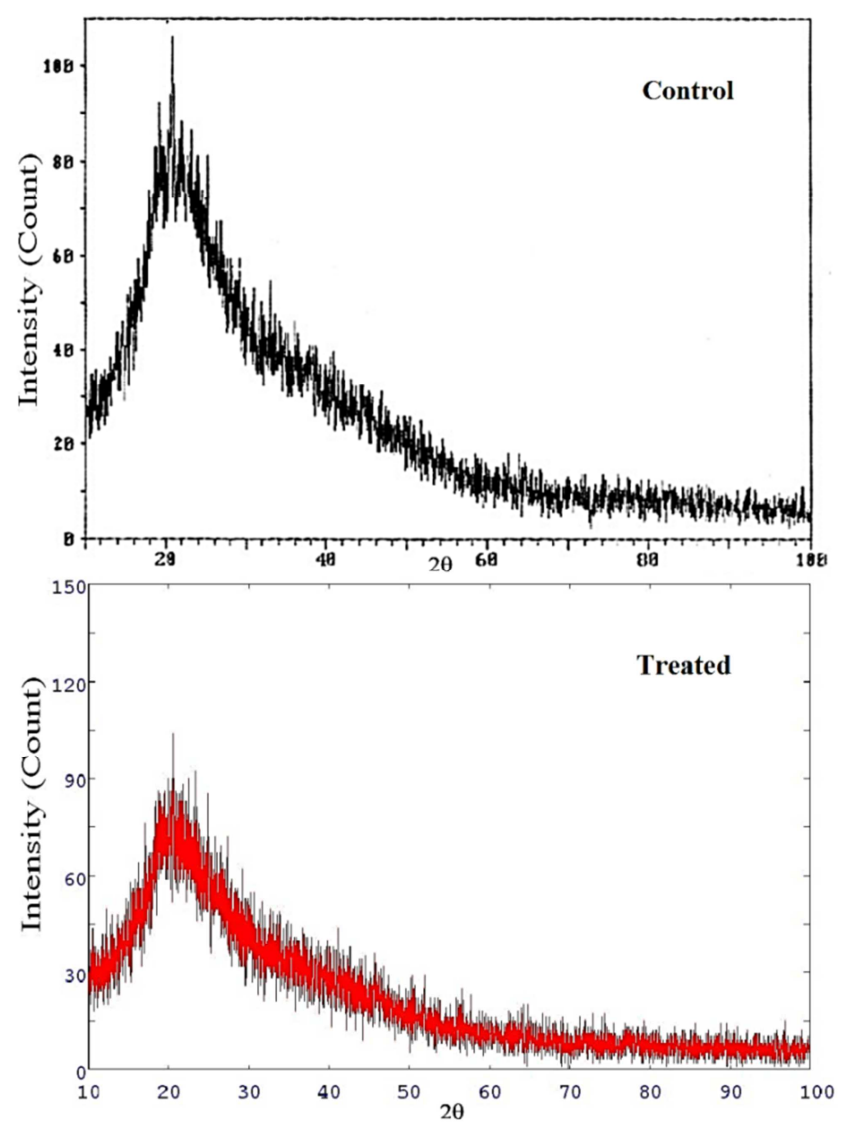

Fig. 1. XRD diffractograms of control and treated protose.

The halo patterns of XRD peaks suggest the amorphous nature of both control and treated samples [21]. The XRD study suggested that biofield energy treatment did not cause any alteration in the physical form of protose with respect to the control sample.

\subsection{Particle Size Analysis}

The average particle size $\left(\mathrm{d}_{50}\right)$ and the particle size below which $99 \%$ particles are present $\left(\mathrm{d}_{99}\right)$ in both the control and treated samples of protose was determined using the laser particle size analyzer, and results are shown in Fig. 2. The particle size result showed the $d_{50}$ of control and treated samples as 8.36 and $9.42 \mu \mathrm{m}$, respectively; and the $\mathrm{d}_{99}$ of control and treated samples as 58.16 and $111.05 \mu \mathrm{m}$, respectively. The results showed about $12.68 \%$ increase in the $\mathrm{d}_{50}$ and $90.94 \%$ increase in the $\mathrm{d}_{99}$ of treated protose as compared to the control protose.

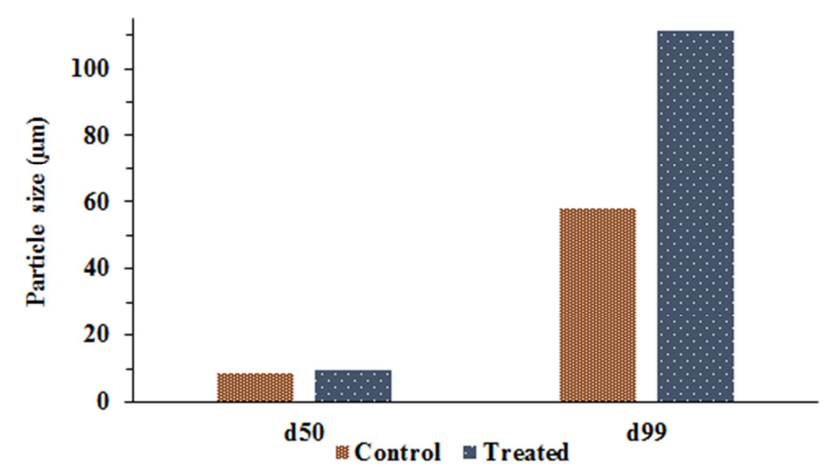

Fig. 2. Particle size of control and treated protose.

It is assumed that the biofield energy probably induce the agglomeration process in treated protose sample, which resulted into increases of average particle sizes of treated sample. Recently, our group reported the biofield induced alteration in the particle size of manganese oxide [22].

\subsection{Surface Area Analysis}

The surface area of control and treated samples of protose was determined using the BET surface area analyzer. The surface area of control and treated samples were found as $1.8137 \mathrm{~m}^{2} / \mathrm{g}$ and $1.7237 \mathrm{~m}^{2} / \mathrm{g}$, respectively. The result showed a decrease in surface area by $4.96 \%$ in the treated sample with respect to the control protose (Fig. 3). It is well reported that surface area is inversely proportional to the particle size [23]. Based on this, it is presumed that biofield energy induced the aggregation of protose particle, which leads to increase the particle size of treated sample with respect to the control. This finding is also supported by the particle size analysis, which showed the significant increases in the particle size of treated sample as compared to the control. Based on this, it is depicted that the surface area of treated sample was decreased substantially due to the effect of biofield energy treatment.

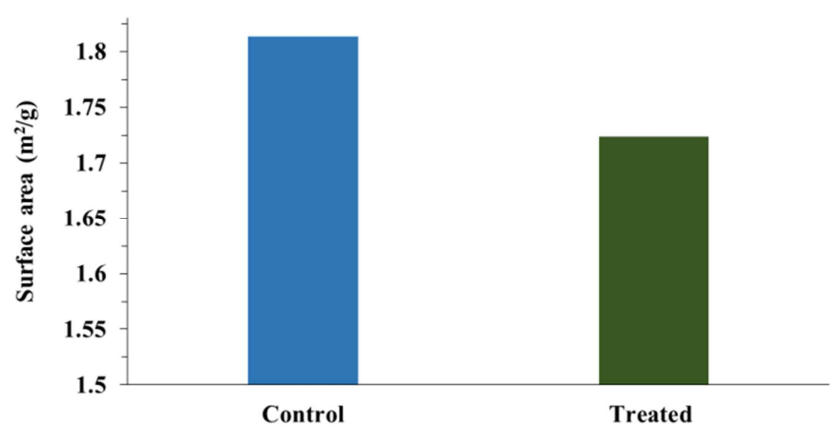

Fig. 3. Surface area of control and treated protose. 


\subsection{DSC Analysis}

DSC analysis was carried out to determine the latent heat of fusion $(\Delta \mathrm{H})$ and melting temperature of protose samples (control and treated). DSC thermograms of control and treated samples are presented in Fig. 4. The melting temperatures of control and treated protose were observed as $204.62^{\circ} \mathrm{C}$ and $197.68^{\circ} \mathrm{C}$.
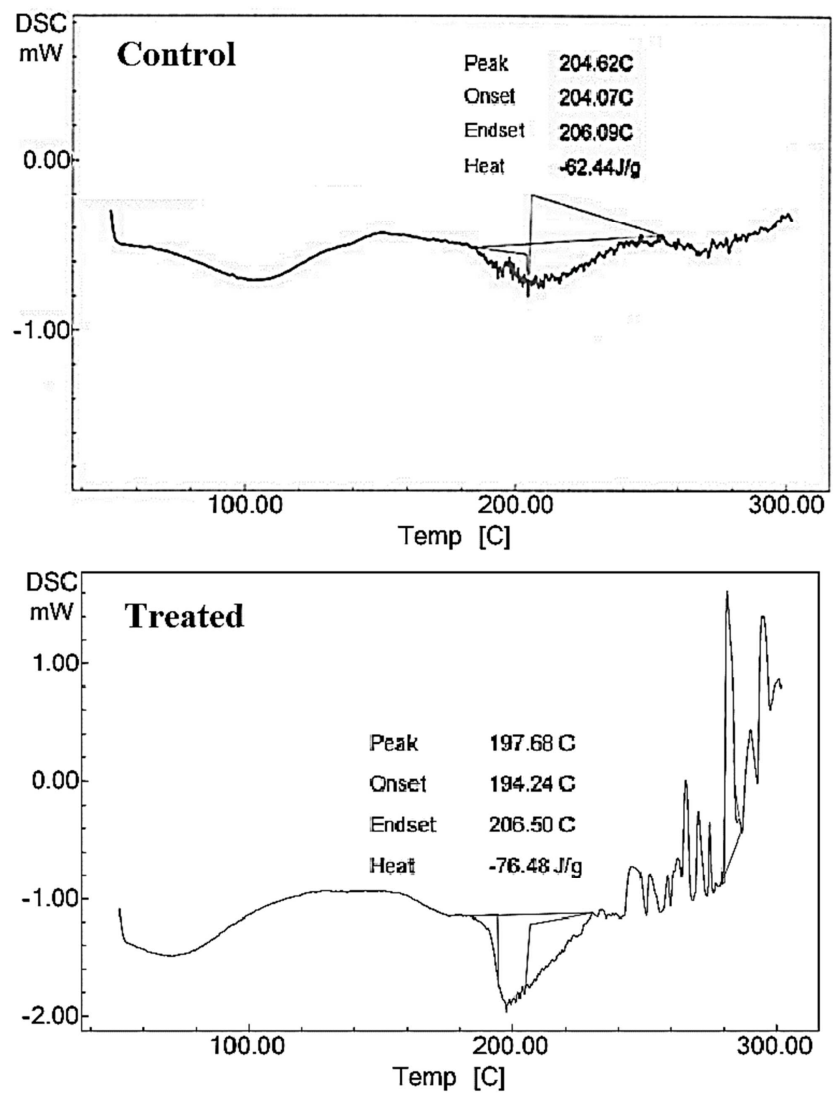

Fig. 4. DSC thermograms of control and treated protose.

The result showed the slight decrease in the melting temperature of treated sample as compared to the control sample (Table 1). Further, the latent heat of fusion corresponding to the control and treated protose samples was observed as $62.44 \mathrm{~J} / \mathrm{g}$ and $76.48 \mathrm{~J} / \mathrm{g}$, respectively (Table 1).

Table 1. Thermal analysis of control and treated samples of protose.

\begin{tabular}{lll}
\hline Parameter & Control & Treated \\
\hline Latent heat of fusion $(\mathrm{J} / \mathrm{g})$ & 62.44 & 76.48 \\
Melting point $\left({ }^{\circ} \mathrm{C}\right)$ & 204.62 & 197.68 \\
Onset temperature $\left({ }^{\circ} \mathrm{C}\right)$ & 273.83 & 258.85 \\
End-set temperature $\left({ }^{\circ} \mathrm{C}\right)$ & 348.27 & 362.22 \\
$\mathrm{~T}_{\max }\left({ }^{\circ} \mathrm{C}\right)$ & 302.48 & 317.65 \\
\hline
\end{tabular}

$\mathrm{T}_{\max }$ : temperature at which maximum weight loss occurs

This showed about $22.49 \%$ increase in the latent heat of fusion of treated protose with respect to the control. It may be due to increase in intermolecular force [24] in treated protose sample as compared to the control protose. As a result, the treated protose sample probably required more energy in the form of latent heat of fusion as compared to the control to change the physical form from solid to gas. Previously, our group has reported that biofield treatment altered the latent heat of fusion of tin and lead metal powders [8]. Therefore, it is expected that biofield treatment might alter the intermolecular interaction of treated protose that may lead to increase in latent heat of fusion.

\subsection{TGA/DTG Analysis}

The TGA/DTG thermogram of control and treated protose samples are shown in Fig. 5, and data are presented in Table 1. The TGA thermogram of control sample showed three steps of thermal degradation. First step was started from $50^{\circ} \mathrm{C}$ (onset) and ended at $100^{\circ} \mathrm{C}$ (endset).

The second step of thermal degradation was started from $189^{\circ} \mathrm{C}$, which was continued up to $235^{\circ} \mathrm{C}$, and the third step was started from $256^{\circ} \mathrm{C}$ and ended at $357^{\circ} \mathrm{C}$. During these three steps of thermal degradation, the weight loss observed was observed as $16.26 \%, 6.52 \%$, and $23.13 \%$, respectively. On the other hand, the treated sample showed two steps of thermal degradation. First step was started from $195^{\circ} \mathrm{C}$ and continued until $245^{\circ} \mathrm{C}$ while the second step was started from $269^{\circ} \mathrm{C}$ that was continued up to $380^{\circ} \mathrm{C}$. During the thermal degradation process in these two steps, the treated sample showed 8.34 and $26.40 \%$ weight loss. The result showed the maximum weight loss during thermal degradation in the third (in control) and second (in treated sample) step. Therefore, these two steps were compared for the thermal study of both the control and treated samples. The result showed about $5.47 \%$ decrease in the onset temperature of thermal degradation of treated sample with respect to the control protose. Moreover, the maximum thermal degradation temperature $\left(T_{\max }\right)$ was observed as $302.48^{\circ} \mathrm{C}$ and $317.65^{\circ} \mathrm{C}$ in control and treated samples, respectively. This showed about $5.66 \%$ increase in the $\mathrm{T}_{\max }$ as compared the control. The increase in $\mathrm{T}_{\max }$ of treated sample might be due to the alteration in internal energy through biofield energy treatment, which results into enhanced thermal stability of treated sample as compared to the control [25]. Based on this it is depicted that the biofield treated protose is more thermally stable than the control sample.

\subsection{FT-IR Spectroscopic Analysis}

The FT-IR spectra of the control and treated protose are shown in Fig. 6. The protose is composed with combinations of proteoses, peptones, amino acids etc. [6]. Due to presence of these different components, it contain several functional groups such as amide $(\mathrm{N}-\mathrm{H}, \mathrm{C}=\mathrm{O})$, aromatic ring $(\mathrm{C}-\mathrm{H}, \mathrm{C}=\mathrm{C})$ etc. The FT-IR spectrum of control sample showed the vibrational peak at $3224 \mathrm{~cm}^{-1}$ that was attributed to $\mathrm{O}-\mathrm{H}$ or $\mathrm{N}-\mathrm{H}$ stretching due to presence of amino acids. This peak was appeared at the upstream frequency region i.e. at $3261 \mathrm{~cm}^{-1}$ in the treated sample.

The stretching frequency of any bond is directly proportional to the force constant and inversely proportional to reduced mass $[26,27]$. Therefore, it is presumed that biofield energy treatment might increase the dipole moment of $\mathrm{N}-\mathrm{H}$ or $\mathrm{O}-\mathrm{H}$ bond in treated protose molecules as compared to 
the control. As a result, the force constant and bond strength of $\mathrm{N}-\mathrm{H}$ or $\mathrm{O}-\mathrm{H}$ group might increase in the treated protose as compared to the control.

Further the vibration peak at $3066 \mathrm{~cm}^{-1}$ in the control sample was attributed to the $=\mathrm{C}-\mathrm{H}$ (aromatic) bond. This peak was observed at the similar frequency region of $3064 \mathrm{~cm}^{-1}$ in the treated sample. The vibrational peak at $2974 \mathrm{~cm}^{-1}$ was assigned to the $=\mathrm{C}-\mathrm{H}$ (aliphatic) peak that was observed at the slightly upstream region i.e. at $2981 \mathrm{~cm}^{-1}$. The IR peaks at 2883 and $1402 \mathrm{~cm}^{-1}$ in the control sample were assigned to the $\mathrm{C}-\mathrm{H}\left(\mathrm{CH}_{3}\right)$ stretching and bending, respectively. These peaks were correspondingly observed at the similar frequency region i.e. at 2881 and $1402 \mathrm{~cm}^{-1}$ in the treated sample [28]. The IR peaks appeared at 1654 and $1541 \mathrm{~cm}^{-1}$ in the control and treated samples were assigned to the amide $\mathrm{C}=\mathrm{O}$ (probably due to presence of amino acids) and $\mathrm{C}=\mathrm{C}$ (aromatic ring) stretchings [29]. The IR peak at $1334 \mathrm{~cm}^{-1}$ in control sample was assigned to $\mathrm{S}=\mathrm{O}$ asymmetric stretching, this was appeared at $1336 \mathrm{~cm}^{-1}$ in the treated sample of protose. The vibrational peaks at 1245 and $1080 \mathrm{~cm}^{-1}$ in the control as well as in the treated sample were attributed to the C-C and C-N stretchings, respectively [28]. Furthermore, the peak at 547 $\mathrm{cm}^{-1}$ in the control sample was assigned to the out of plane ring deformation of aromatic ring, which was shifted to the lower frequency region of $540 \mathrm{~cm}^{-1}$ in the treated sample. This showed the increase in the flexibility of aromatic ring in the treated sample as compared to the control. Overall, the FT-IR study suggested the significant impact of biofield energy treatment on bond strength and force constant of some functional groups like $\mathrm{C}=\mathrm{O}, \mathrm{C}-\mathrm{H}, \mathrm{N}-\mathrm{H}, \mathrm{O}-\mathrm{H}$ etc.
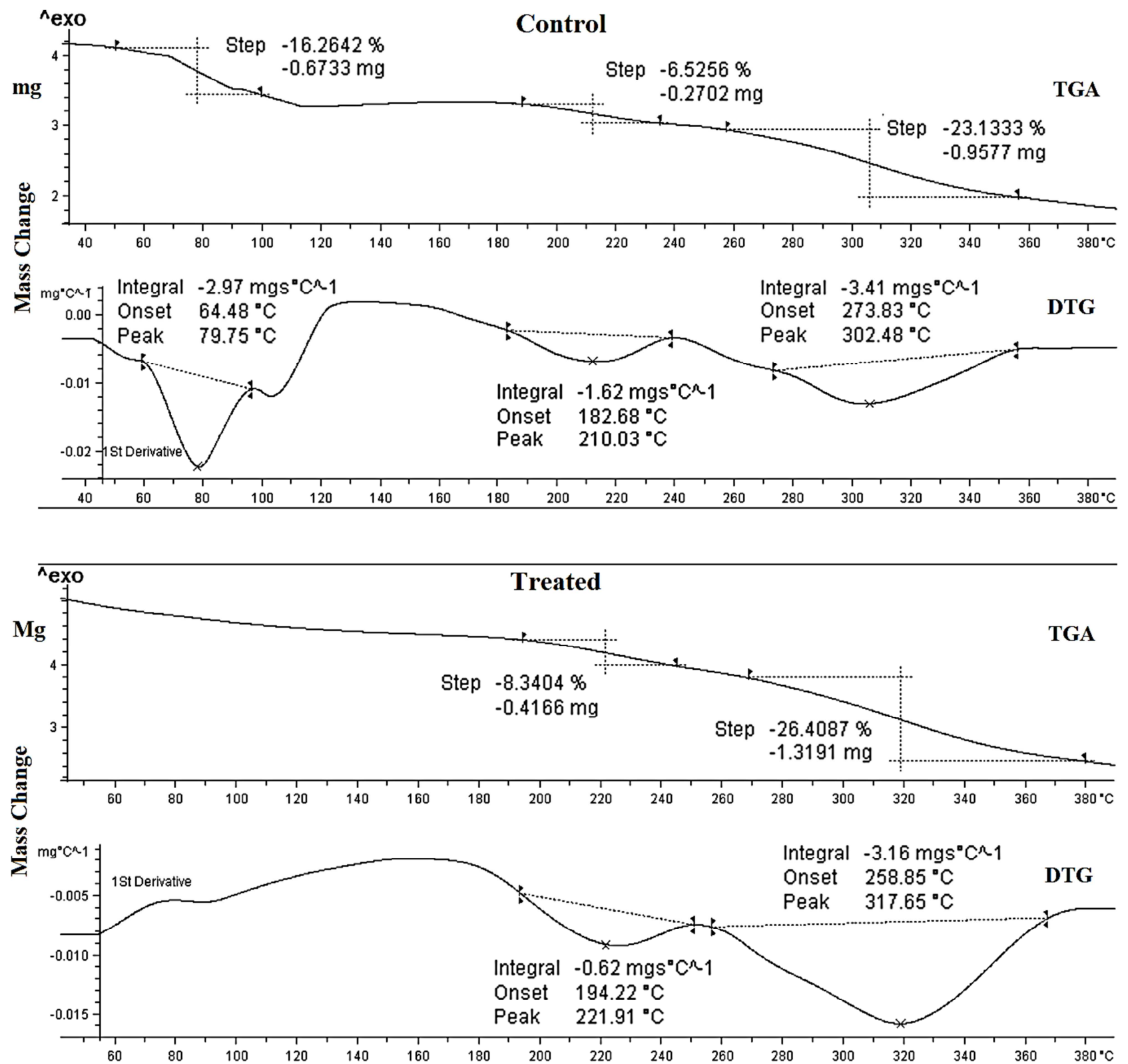

Fig. 5. TGA/DTG thermograms of control and treated protose. 

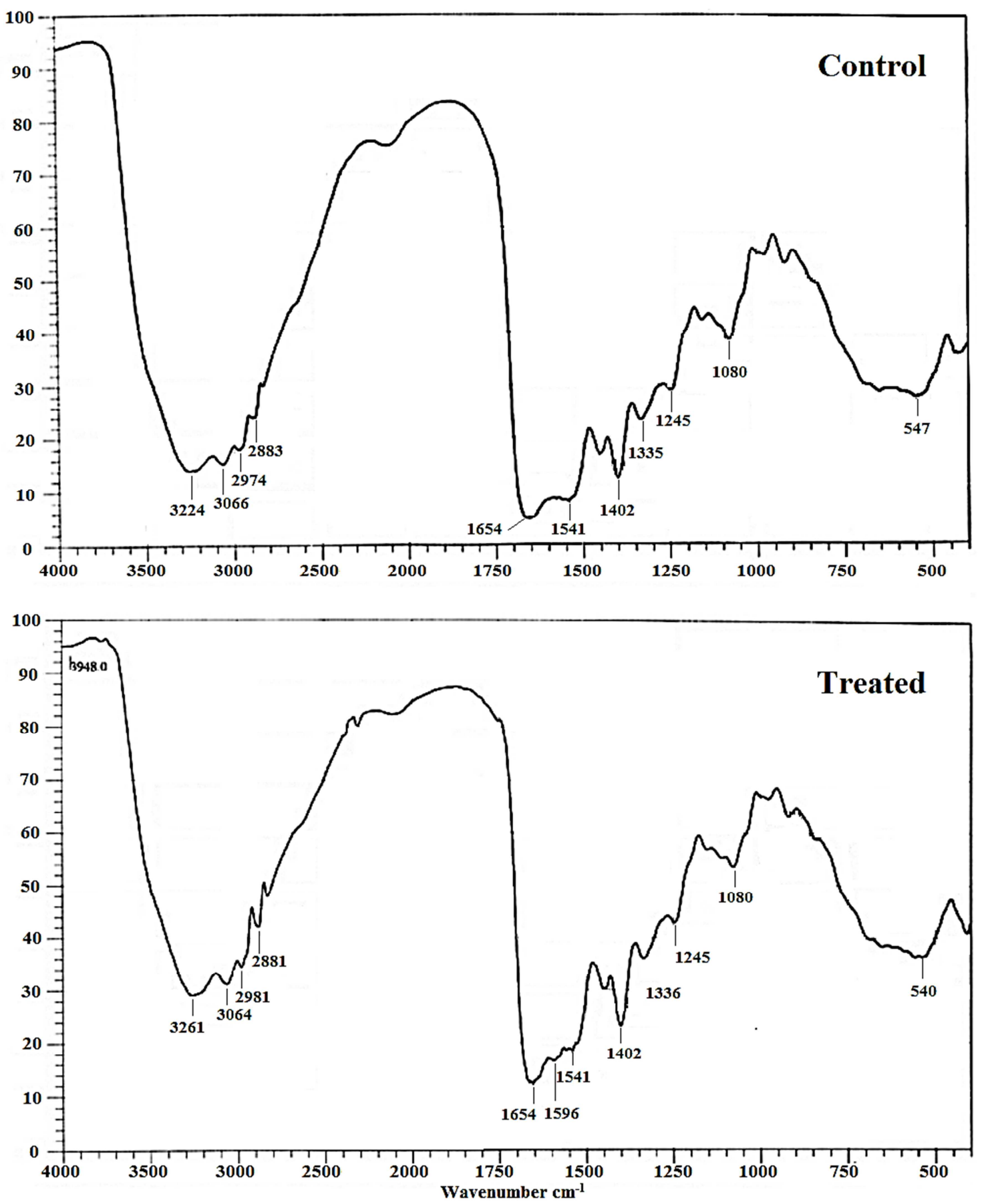

Fig. 6. FT-IR spectra of control and treated protose.

\section{Conclusion}

In conclusion, the XRD study showed the amorphous nature of protose in both the samples (control and treated). The particle size analysis suggested the significant increase in the particle size i.e. $\mathrm{d}_{50}$ and $\mathrm{d}_{99}$ of the treated protose with respect to the control. This was also supported by the corresponding decrease in the surface area of treated sample as compared to the control. The DSC study revealed the significant increase in the latent heat of fusion by $22.49 \%$ in treated protose with respect to the control. The TGA/DTG study showed the slight increase in $\mathrm{T}_{\max }$ by $5.66 \%$ as compared to the control. This showed the increase in thermal stability of treated protose as compared to the corresponding control sample. Moreover, the FT-IR study revealed the increase in wavenumber of $\mathrm{O}-\mathrm{H}, \mathrm{N}-\mathrm{H}, \mathrm{S}=\mathrm{O}$, and $\mathrm{C}-\mathrm{H}$ (methyl) stretching after biofield treatment with respect to the control sample.

Overall, the present study concluded the considerable impact of Mr. Trivedi's biofield energy treatment on physical, thermal and spectroscopic properties of protose. Based on this, it is anticipated that Mr. Trivedi's biofield energy treatment can modify the physicochemical properties of protose so that it 
could be utilized as a better culture medium for the production of enzymes, antibiotics, and veterinary preparations.

\section{Abbreviations}

NIH: National Institute of Health; NCCAM: National Center for Complementary and Alternative Medicine; XRD: X-ray diffraction; DTG: Derivative Thermogravimetry; TGA: Thermogravimetric Analysis

\section{Acknowledgments}

The authors would like to thank the Trivedi Testimonials, Trivedi Science, and Trivedi Master Wellness for their support during the study. Authors would also like to acknowledge the whole scientific team of MGV pharmacy college, Nashik for allowing the instrumental facility.

\section{References}

[1] Urry LA (2013) e-Study guide for campbell biology in focus. (1stedn), Cram 101 textbook reviews. eISBN 9781478445562.

[2] Park B, Lu R (2015) Hyperspectral imaging technology in food and agriculture. Springer technology \& engineering. Media LLC, New York.

[3] http://2.imimg.com/data2/TS/YC/MY-1034079/animal-originpeptones-protein-hydrolysates.pdf

[4] Pasupuleti VK, Braun S (2010) Protein Hydrolysates in Biotechnology. State of the Art Manufacturing of Protein Hydrolysates. Springer Science \& Business Media. New York.

[5] http://www.neogen.com/Acumedia/pdf/MediaIngredients.pdf

[6] http://himedialabs.com/TD/RM280.pdf

[7] Lenssen AW (2013) Biofield and fungicide seed treatment influences on soybean productivity, seed quality and weed community. Agricultural Journal 8: 138-143.

[8] Trivedi MK, Patil S, Tallapragada RM (2013) Effect of bio field treatment on the physical and thermal characteristics of silicon, tin and lead powders. J Material Sci Eng 2: 125.

[9] Koithan M (2009) Introducing complementary and alternative therapies. J Nurse Pract 5: 18-20.

[10] Rubik B (2008) Measurement of the human biofield and other energetic instruments, Chapter 20 of energetics and spirituality by Lyn Freeman.

http://www.faim.org/energymedicine/measurement-human-bio field.html.

[11] Ho MW (1995) Bioenergetics and the coherence of organisms. Neuronetwork World 5: 733-750.

[12] Gough WC (1999) The cellular communication process and alternative modes of healing. Subtle Energies Energy Med 8: 67-101.
[13] Warber SL, Cornelio D, Straughn J, Kile G (2004) Biofield energy healing from the inside. J Altern Complement Med 10: 1107-1113.

[14] Chang PL (2015) What is the human biofield and the role of biophotons?

http://energyfanatics.com/2015/01/02/what-is-human-biofieldrole-biophotons.

[15] Stenger VJ (1999) Bioenergetic fields. Sci Rev Alternative Med 3. http://www.colorado.edu/philosophy/vstenger/Medicine/Biofield. html

[16] Shinde V, Sances F, Patil S, Spence A (2012) Impact of biofield treatment on growth and yield of lettuce and tomato. Aust $\mathrm{J}$ Basic Appl Sci 6: 100-105.

[17] Sances F, Flora E, Patil S, Spence A, Shinde V (2013) Impact of biofield treatment on ginseng and organic blueberry yield. Agrivita, J Agric Sci 35.

[18] Nayak G, Altekar N (2015) Effect of biofield treatment on plant growth and adaptation. J Environ Health Sci 1: 1-9.

[19] Trivedi MK, Nayak G, Patil S, Tallapragada RM, Jana S, et al. (2015) Bio-field treatment: An effective strategy to improve the quality of beef extract and meat infusion powder. J Nutr Food Sci 5: 389 .

[20] Pavia DL, Lampman GM, Kriz GS (2001) Introduction to spectroscopy. (3rdedn), Thomson Learning, Singapore.

[21] Chauhan A, Chauhan P (2014) Powder XRD technique and its applications in science and technology. J Anal Bioanal Tech 5: 212.

[22] Trivedi MK, Nayak G, Patil S, Tallapragada RM, Latiyal O (2015) Evaluation of biofield treatment on physical, atomic and structural characteristics of manganese (II, III) oxide. J Material Sci Eng 4: 177.

[23] Groza JR, Shackelford JF (2007) Materials processing handbook. Taylor and Francis group, CRC Press.

[24] Cairo JM (2013) Mosby's respiratory care equipment. (9thedn), Elsevier health sciences, St. Louis Missouri.

[25] Spear RJ, Maksacheff M (1986) The relationship between ignition temperature and thermal stability for selected primary explosives. Thermochim Acta 105: 287-293.

[26] Smith BC (1998) Infrared spectral interpretation: A systematic approach. CRC Press.

[27] Chaban GM, Huo WM, Lee TJ (2002) Theoretical study of infrared and Raman spectra of hydrated magnesium sulfate salts. The J Chem Phys 117: 2532-2537.

[28] http://www.instruction.greenriver.edu/kmarr/chem $\% 20162 / \mathrm{Ch}$ em162\%20Labs/Interpreting\%20IR\%20Spectra/IR\%20Absor ptions $\% 20$ for $\% 20$ Functional\%20Groups.htm

[29] Lin-Vien D, Colthup NB, Fateley WG, Grasselli JG (1991) The handbook of infrared and Raman characteristic frequencies of organic molecules. Academic press, San Diego, New York. 